\title{
Evaluation of Transoperatory Ventilation Modalities by a Questionnaire
}

\author{
Angel Soubhie ${ }^{1}$, Enis Donizetti Silva, TSA 2, Claudia Marquez Simões, TSA ${ }^{3}$, Fábio Henrique Gregory, TSA 2, \\ Arthur Vitor Segurado, TSA ${ }^{4}$, Cássio Campello de Menezes, TSA 5
}

Summary: Soubhie A, Silva ED, Simões CM, Gregory FH, Segurado AV, Menezes CC - Evaluation of Transoperatory Ventilation Modalities by a Questionnaire.

Background and objectives: Anesthesia devices have been making it possible to reduce the physiological repercussions and problems caused by mechanical ventilation. The objective of this study was to evaluate, retrospectively, ventilatory methods and support resources used by a group of anesthesiologists in patients without prior lung damage in the intraoperative period.

Methods: A non-identifiable questionnaire composed of 27 questions was applied to a group of anesthesiologists and anesthesiology residents who work at different private hospitals in the city of São Paulo. The questionnaires were applied over a 15-day period. Ventilation patterns, positive end-expiratory pressure (PEEP), alveolar recruitment maneuvers, and the calculation of the tidal volume used with tracheal intubation were observed.

Results: Participants were predominantly males, $40.5 \%$ bearing the Anesthesiology Superior Title (TSA), and the majority concluded their residency less than 10 years ago. Most anesthesiologists used PEEP, between 5 and $10 \mathrm{cmH}_{2} \mathrm{O}$, routinely. Fresh gas flow above $1,000 \mathrm{~mL}$.min ${ }^{-1}$ is still used by most anesthesiologists. Alveolar recruitment maneuvers were performed by $80 \%$ of those interviewed, shortly after intubation and before removing the ET tube with the most common strategy insufflation with $40 \mathrm{cmH}_{2} \mathrm{O}$ for 15 seconds. As for strategies to protect ventilation, only $30 \%$ used a tidal volume with less than $7 \mathrm{~mL} . \mathrm{kg}^{-1}$ with inspired oxygen fraction between $40 \%$ and $60 \%$.

Conclusions: This descriptive study allows us to state that in the hospitals evaluated the majority of anesthesiologists uses resources to minimize eventual repercussions of controlled mechanical ventilation. This data can orient the development of continuing medical education programs in mechanical ventilation associated with anesthesia aiming to safety and improvement of patient care.

Keywords: EQUIPMENT: ventilator; VENTILATION: controlled mechanical, positive end-expiratory pressure.

[Rev Bras Anestesiol 2010;60(4): 415-421] @Elsevier Editora Ltda.

\section{INTRODUCTION}

Mechanical ventilation (MV) represents a method of temporary substitution of normal respiratory function. It contributes for increasing survival in many clinical situations, but when improperly used it increases the morbidity and mortality rates. The evolution of anesthesia devices, by means of introducing new safety and monitoring resources, allows the reduction of the physiological repercussions and problems caused by MV.

General anesthesia with MV can lead to the development of atelectasis, reduction in lung volume, and reduction of functional residual capacity (FRC), resulting in an increase in in-

Received from Hospital Sírio Libanês - Serviços Médicos de Anestesia Ltda.

1. Anesthesiologist of the Cancer Institute of Estado de São Paulo (ICESP, from the Portuguese) and of São Paulo Serviços Médicos de Anestesia Ltda.

2. Anesthesiologist: Co-responsible for CET São Paulo Serviços Médicos de Anestesia Ltda.

3. Coordinator of the Anesthesia Service of ICESP, of Secretaria de Estado da Saúde and

Faculdade de Medicina da Universidade de São Paulo; Co-responsible for CET São Paulo

Serviços Médicos de Anestesia Ltda.

4. Anesthesiologist of CET São Paulo Serviços Médicos de Anestesia Ltda.

5. Anesthesiologist; Responsible for CET São Paulo Serviços Médicos de Anestesia Ltda.

Submitted on October 11, 2009

Approved on March 24, 2010

Correspondence to:

Dra. Claudia Marquez Simões

R. Dona Adma Jafet, 50 - conjunto 31, Bela Vista

01308-050 - São Paulo, SP

E-mail: claucms@terra.com.br trapulmonary shunt that can lead to postoperative decrease in arterial and tissue oxygenation. Ventilatory support also causes changes in the muscular respiratory work resulting from a reduction in complacence of the respiratory system and increase in airways resistance to the flow of gas.

Those changes can become more severe depending on the surgical technique or patient characteristics. Laparoscopic surgeries (reduced FRC by the pneumoperitoneum and predisposition to form atelectasis), surgeries with monopulmonary ventilation, cardiac surgeries (the lungs are not ventilated during extracorporeal circulation), and obese (reduced FRC) and pediatric (when maintained in spontaneous ventilation) patients can evolve with worse postoperative arterial oxygenation.

Some maneuvers have been studied to avoid the changes mentioned. The use of positive end-expiratory pressure (PEEP) and alveolar recruitment maneuvers (ARM) are important resources to recruit collapsed alveolar units, increasing the lung area available for gas exchange.

With the development and modernization of ventilators, new flow patterns have been used, decreasing the physiological disruption. The current tendency is to use decelerating flow ventilation, therefore minimizing the hemodynamic and ventilatory repercussions with better pattern of pulmonary distribution.

Even for a short period, mechanical ventilation implies significant inflammatory changes in the lungs. The protective ventilation strategy with low tidal volume $\left(<7 \mathrm{~mL}^{\mathrm{kg}} \mathrm{kg}^{-1}\right)$ asso- 
ciated with PEEP limits those changes by reducing the levels of inflammatory mediators, both in the lungs and systemically, in patients without preexisting lung disease.

Patients ventilated with high tidal volumes without PEEP have permanent mechanical and histological changes in the airways, besides pro-coagulation and inflammatory activities in the lungs. This ventilatory strategy promotes deposition of fibrin in the airways by three mechanisms: increased pro-coagulant activity, relative protein $\mathrm{C}$ insufficiency, and inhibition of fibrinolysis. Fibrin deposits lead to inactivation or reduction of the surfactant, provoking alveoli instability and collapse.

So far, it is not possible to state that a standardized MV in anesthesia exists considering different situations such as duration of the procedure, type of surgical intervention, and preoperative pulmonary capacity.

The objective of the present study was to evaluate retrospectively the ventilatory profile used in different intraoperative situations.

\section{METHODS}

A non-identifiable questionnaire composed of 27 objective questions was sent to a group of anesthesiologists who work in three different private tertiary hospitals in the city of São Paulo (Hospital Sírio-Libanês, Hospital Alemão Oswaldo Cruz, and Hospital Samaritano). This group has a total of 60 anesthesiologists and eight residents (first, second and third year residents of the program of Medical Residency in Anesthesiology of the Hospital Sírio-Libanês).

The questionnaires were applied at the different hospitals during a 15-day period. All questions involved situations in which patients did not have pulmonary diseases. Thoracic and cardiac surgeries were excluded.

Anesthesiologists were classified according to gender, time in Anesthesiology, and whether they held an Anesthesiology Superior Title (TSA, from the Portuguese). Data on ventilatory patterns used, resources available for monitoring ventilation, use of PEEP, alveolar recruitment, calculus of the tidal volume used, and use of the laryngeal mask were all collected.

\section{RESULTS}

During the evaluation period, out of 60 anesthesiologists, five were on vacation (8.3\%), one resident was on an external rotation (1.6\%), and 17 did not want to participate (28.3\%) for a total of 37 questionnaires answered. The population was predominantly male $(70.3 \%), 40.5 \%$ had the TSA, and the majority had concluded their residency less than 10 years ago (64.9\%). Most participants had available a transport ventilation device (91.9\%) (Table I).

The majority of anesthesiologists (94.6\%) used PEEP routinely. Out of those, $65.4 \%$ use levels of PEEP between 5 and $10 \mathrm{cmH}_{2} \mathrm{O}$. When questioned about the calculations used to obtain the level of PEEP, $80 \%$ were based on physiological levels, $5.7 \%$ used the pressure-volume curve, $5.7 \%$ were based on the levels of pulmonary complacency, and $5.7 \%$ used other type of calculation. Fresh gas flow over 1,000 mL. $\mathrm{min}^{-1}$ is used by $59.5 \%$ of the professional, and $86.5 \%$ use a $\mathrm{FiO}_{2}$ ranging from 40 to $60 \%$. Among those interviewed, $78.4 \%$ performed intraoperative alveolar recruitment maneuvers after intubation $(27.7 \%)$, before removing the ET tube $(40.5 \%)$ or in both moments $(24.3 \%)$, and the most common strategy used is insufflation with $40 \mathrm{cmH}_{2} \mathrm{O}$ for 15 seconds (41.8\%).

As for strategies to protect ventilation, only $30 \%$ use a tidal volume lower than $7 \mathrm{~mL} \cdot \mathrm{kg}^{-1}$, and $70 \%$ use volumes between 7 and 10 mL. $\mathrm{kg}^{-1}$. Most anesthesiologists interviewed use an inspired fraction of oxygen between 40 and $60 \%$ (86.5\%), and only $13.5 \%$ use $\mathrm{FiO}_{2}$ below $40 \%$ (Table II).

Table I - Demographic Characteristics

\begin{tabular}{ll}
\hline TSA & \\
Yes & $40.5 \%$ \\
No & $40.5 \%$ \\
Gender & \\
$\quad$ Female & $29.7 \%$ \\
$\quad$ Male & $70.3 \%$ \\
Time after the end of residency & \\
$\quad$ < years & $35.1 \%$ \\
5 to10 years & $29.8 \%$ \\
$>10$ years & $35.1 \%$ \\
\hline
\end{tabular}

Table II - Results

\begin{tabular}{|c|c|}
\hline \multicolumn{2}{|l|}{ Use of PEEP } \\
\hline Yes & $5.4 \%$ \\
\hline No & 94.5 \\
\hline \multicolumn{2}{|l|}{ PEEP Calculation } \\
\hline Physiological & $80.1 \%$ \\
\hline Pressure-volume curve & $8.5 \%$ \\
\hline $\mathrm{PaO}_{2} / \mathrm{FiO}_{2}$ & $0 \%$ \\
\hline Pulmonary complacence & $5.7 \%$ \\
\hline Others & $5.7 \%$ \\
\hline \multicolumn{2}{|l|}{ Level of PEEP } \\
\hline$<5 \mathrm{cmH}_{2} \mathrm{O}$ & $34.3 \%$ \\
\hline $5-10 \mathrm{cmH}_{2} \mathrm{O}$ & $65.7 \%$ \\
\hline$>10 \mathrm{cmH}_{2} \mathrm{O}$ & $0 \%$ \\
\hline \multicolumn{2}{|l|}{ Inspired fraction of oxygen } \\
\hline$<40 \%$ & $13.5 \%$ \\
\hline $40-60 \%$ & $86.5 \%$ \\
\hline$>60 \%$ & $0 \%$ \\
\hline \multicolumn{2}{|l|}{ Fresh gas flow } \\
\hline Below 1,000 mL. $\mathrm{min}^{-1}$ & $40.5 \%$ \\
\hline Above $1,000 \mathrm{~mL} \cdot \mathrm{min}^{-1}$ & $59.5 \%$ \\
\hline \multicolumn{2}{|l|}{ Alveolar recruitment } \\
\hline Yes & $78.4 \%$ \\
\hline No & $21.6 \%$ \\
\hline \multicolumn{2}{|l|}{ Time of recruitment } \\
\hline After intubation & $27.7 \%$ \\
\hline Before extubation & $40.5 \%$ \\
\hline In both moments & $23.4 \%$ \\
\hline \multicolumn{2}{|l|}{ Tidal volume } \\
\hline$<5 \mathrm{~mL} \cdot \mathrm{kg}^{-1}$ & $2.7 \%$ \\
\hline 5-7 mL. $\mathrm{kg}^{-1}$ & $27 \%$ \\
\hline 7-10 mL.kg-1 & $70.3 \%$ \\
\hline
\end{tabular}




\section{DISCUSSION}

This descriptive study allows us to state that in the hospitals evaluated the patterns of mechanical ventilation adopted are aimed at minimizing the repercussion of controlled mechanical ventilation by using resources like PEEP and ARM.

Almost all anesthesiologists use PEEP routinely with levels from 5 to $10 \mathrm{cmH}_{2} \mathrm{O}$. Intraoperative ARM, used by $68.2 \%$ of the anesthesiologists interviewed, improves postoperative oxygenation and reverses atelectasis in patients under general anesthesia. Thus, it interferes positively in post-anesthetic recovery of patients reducing the need of postoperative oxygen supplementation and pulmonary complications.

On the other hand, protective strategies of mechanical ventilation, such as using low inspired oxygen fractions, low flow of fresh gases, and low tidal volume could be used more widely in anesthesia with potential benefits for patients.

The choice of inspired fraction of oxygen $\left(\mathrm{FiO}_{2}\right)$ is an important factor, especially in cases with prolonged mechanical ventilation. It is known that oxygen toxicity has a direct relationship to the concentration and the time of exposure. High concentrations can cause damage by hyperoxia and microatelectasis due to absorption. Currently, $\mathrm{a} \mathrm{FiO}_{2}$ between 40 and $50 \%$ is considered safe.

The fresh gas flow used was above the predicted to characterize low flow anesthesia $\left(1,000 \mathrm{~mL} \cdot \mathrm{min}^{-1}\right)$, allowing the conclusion that it is not commonly used in the hospitals evaluated. This anesthetic technique conserves the humidity and temperature of the airways and promotes a reduction in envi- ronmental pollution and consumption of inhalational anesthetics. However, it requires close monitoring due to the potential risk of hypoxemia and hypercapnia.

Mechanical ventilation with high tidal volumes represents a pro-inflammatory stimulus in healthy lungs. The inflammatory responses observed are adaptation to the process of artificial MV. Patients ventilated with low tidal volumes are at a lower risk of pulmonary infections, besides decreasing the length of stay in intensive care units.

Ventilation during anesthesia should take into consideration the anatomical, physiological, and pathologic particularities of each patient, and it is up to the anesthesiologist to implement new concepts that increase safety, reduce costs, and increase efficacy without compromising oxygenation and ventilation. The knowledge of those resources that in the past were only available in intensive care units is essential. New anesthesia devices have new ventilatory strategies that adequate the ventilatory support of severely ill patients, who are increasingly undergoing more surgical or diagnostic procedures that need anesthesia and controlled mechanical ventilation.

The results of the present study indicate the need of standardizing mechanical ventilation. It would be necessary to document the clinical evolution of those patients to determine the characteristics related to the length of anesthesia, type of surgery, and the patient, constituting an agenda for future studies. Few epidemiological studies on intraoperative ventilation patterns are available, and the results obtained by this questionnaire provide a guideline for continuing medical education actions to improve care. 


\section{REFERÊNCIAS / REFERENCES}

01. Wolthuis EK, Choi G, Dessing MC et al. - Mechanical ventilation with lower tidal volumes and positive end-expiratory pressure prevents pulmonary inflammation in patients without preexisting lung injury. Anesthesiology, 2008;108:46-54.

02. Choi G, Wolthuis EK, Bresser P et al. - Mechanical ventilation with lower tidal volumes and positive end-expiratory pressure prevents alveolar coagulation in patients without preexisting lung injury. Anesthesiology, 2006;105: 689-695.

03. Gonçalves LO, Cicarelli DD - Manobra de recrutamento alveolar em anestesia: como, quando e por que utilizá-la. Rev Bras Anestesiol, 2005;55:631-638. 
04. Vieira JE, Silva BAR, Garcia Jr D - Padrões de ventilação em anestesia. Estudo retrospectivo. Rev Bras Anestesiol, 2002;52:756-763.

05. Rothen HU, Sporre B, Engberg G et al. - Influence of gas composition on recurrence of atelectasis after a reexpansion maneuver during general anesthesia. Anesthesiology, 1995;82:832-842.

06. Torres MLA, Carvalho EA, Yamashiro JR et al. - Análise crítica em relação ao custo de anestésicos inalatórios no HC-FMUSP, comparando-se a técnica de alto fluxo com a de baixo fluxo de gases frescos. Rev Bras Anestesiol, 2000;50:(Supl 25):CBA005B.

07. Auler Jr JOC, Ruiz Neto PP - Alterações pulmonares da anestesia. Rev Bras Anestesiol, 1992;42:(Supl 14):s15-s24.

08. Hess DR, Bigatello LM - Lung recruitment: the role of recruitment maneuvers. Respir Care, 2002;47:308-317.

09. Claxton BA, Morgan $\mathrm{P}$, McKeague $\mathrm{H}$ et al. - Alveolar recruitment strategy improves arterial oxygenation after cardiopulmonary bypass. Anaesthesia, 2003;58:111-116.

10. Dyhr $\mathrm{T}$, Nygard $\mathrm{E}$, Laursen $\mathrm{N}$ et al. - Both lung recruitment maneuver and PEEP are needed to increase oxygenation and volume after cardiac surgery. Acta Anaesthesiol Scand, 2004; 48:187-197.

11. Tusman G, Bohm SH, Sipmann FS et al. - Lung recruitment improves the efficiency of ventilation and gas exchange during one-lung ventilation anesthesia. Anesth Analg, 2004;98:1604-1609.

Resumen: Soubhie A, Silva ED, Simões CM, Gregory FH, Segurado AV, Menezes CC - Evaluación de las Modalidades Ventilatorias en el Período Transoperatorio por medio de Cuestionario.

Justificativa y objetivos: Los aparatos de anestesia han venido posibilitando la reducción de las repercusiones fisiológicas y de los problemas causados por la ventilación mecánica. El objetivo de este estudio fue evaluar de forma retrospectiva, los métodos y los recursos de ayuda ventilatoria utilizados por un grupo de anestesiólogos en pacientes sin lesión pulmonar previa en el período intraoperatorio.

Método: Un cuestionario no identificado, con 27 preguntas objetivas, se aplicó a un grupo compuesto por médicos anestesiólogos y en especialización que actúan en diferentes hospitales privados en la ciudad de São Paulo. Los cuestionarios se aplicaron en un período de 15 días. Se observaron los estándares ventilatorios, la presión positiva al final de la expiración (PEEP), el reclutamiento alveolar y el cálculo del volumen corriente que se usó con intubación traqueal.

Resultados: Los participantes fueron predominantemente del sexo masculino, un 40,5\% con título superior en Anestesiología (TSA), y la mayoría que terminó la especialización hace menos de 10 años. La mayor parte de los anestesiólogos utiliza el PEEP como rutina, entre 5 y $10 \mathrm{cmH} 2 \mathrm{O}$. Gran parte de los anestesiólogos todavía usa el flujo de gases frescos por encima de $1000 \mathrm{~mL}$.min-1. Las maniobras de reclutamiento alveolar son hechas por un $80 \%$ de los entrevistados después de la intubación y antes de la retirada de los tubos, siendo la estrategia más común la insuflación con $40 \mathrm{cmH} 2 \mathrm{O}$ por 15 segundos. En cuanto a las estrategias protectoras de ventilación, apenas $30 \%$ utilizan volumen corriente $<7 \mathrm{~mL} . \mathrm{kg}^{-1}$, con fracciones inspiradas de oxígeno entre 40 y $60 \%$.

Conclusiones: Este estudio descriptivo permite afirmar que en los hospitales evaluados, gran parte de los anestesiólogos utiliza recursos para minimizar una eventual repercusión de la ventilación controlada mecánica. Esos datos pueden orientar el desarrollo de programas de educación médica continua en ventilación mecánica, asociada a la anestesia para garantizar así la seguridad y la mejoría de la atención al paciente. 